\title{
Pembinaan Akhlak Dengan Metode IDT (Ikhtiar, Doa, Takwa) \\ (Penelitian di SMP IT AL WASI Cisompet)
}

\author{
Dena Sri Anugrah ${ }^{1}$ Siti Sopiah Hamdaniyah ${ }^{2}$ Muhammad Rijali $^{3}$, Jafar Amirudin ${ }^{4}$ \\ Universitas Garut \\ denasrie2@gmail.com ${ }^{1}$, hamdaniyyah77@gmail.com ${ }^{2}$, \\ rijalimuhammad589@gmail.com ${ }^{3}$, Jafar.amirudin24@gmail.com ${ }^{4}$
}

\begin{abstract}
Abstrak
Pembinaan akhlak sangat penting dilakukan dalam usaha pencegahan dampak negatif perkembangan zaman. Penelitian ini dilatarbelakangi oleh banyaknya perilaku menyimpang dikalangan peserta didik. Kurang efektifnya pembinaan akhlak yang dilakukan keluarga, sekolah maupun masyarakat, longgarnya pegangan terhadap agama merupakan beberapa alasan adanya degradasi akhlak. Penelitian ini bertujuan untuk menciptakan generasi penerus yang memiliki nilai, beradab serta mampu menghadapi berbagai persoalan kehidupan menurut norma yang berlaku. Penelitian ini dilakukan melalui pendekatan kualitatif dengan menggunakan metode observasi, wawancara dan dokumentasi. Sumber data primer penelitian ini adalah kepala sekolah, guru, orang tua dan peserta didik SMP IT Al Wasi. Sedangkan untuk data sekundernya diperoleh dari studi kepustakaan dengan mengumpulkan, membaca dan mengulas buku-buku yang berkaitan dengan pembinaan akhlak peserta didik. Data dianalisis dengan kualitatif melalui teknik analisis reduksi data (data reduction), penyajian data (data display) dan penarikan kesimpulan (verifikasi). Hasil penelitian menunjukan bahwa pembinaan akhlak peserta didik SMP IT Al Wasi terimplementasikan ke dalam program rutinitas yang menjadi keharusan bagi peserta didik melalui metode IDT (Ikhtiar, Doa, Takwa). Konsep ikhtiar sebagai langkah pertama seorang Muslim dalam membina akhlak mulai dari akhlak terhadap manusia sampai akhlak terhadap Allah SWT, kemudian diiringi doa serta takwa terhadap Allah SWT. Namun, peneliti menemukan bahwa penghambat pembinaan akhlak peserta didik SMP IT Al Wasi adalah dari lemahnya pertahanan personal peserta didik dalam mengikuti perkembangan zaman sehingga mudah dipengaruhi oleh teman, dikarenakan kurangnya perhatian orang tua terhadap anak, latar belakang keluarga yang kurang harmonis (broken home) dan ekonomi lemah, ketidaklancaran dana pendidikan serta kurangnya masyarakat sekitar dalam membantu kelancaran proses pendidikan.
\end{abstract}


Kata Kunci: Pembinaan Akhlak, Peserta Didik, Metode IDT

\section{Pendahuluan}

Salah satu pilar utama yang menjadi kebanggaan umat Islam adalah dibangunnya satu sistem perilaku yang menjadi modal dasar seorang muslim untuk menjalani hidup, termasuk didalamnya bagaimana bermuamalah atau bersosialisasi antar sesama manusia. Sistem tersebut merupakan panduan langsung yang berasal dari Allah, kemudian dibawakan oleh para nabi dan rasul Allah melalui syi'ar dan perilaku sehari-hari serta dalam berbagai isi kitab. Sistem tersebutlah yang kemudian kita kenal sebagai Akhlaqul Karimah atau "Sebaik-baik Akhlak".

Peran akhlak dalam kehidupan manusia menempati tempat yang penting baik secara individu maupun sebagai anggota masyarakat. Kata "akhlak" berasal dari bahasa Arab, yaitu jamak dari kata "خلق" yang secara bahasa diartikan dengan budi pekerti, perangai, tingkah laku atau tabiat, tata krama, sopan santun, adab, dan tindakan. Kata akhlak juga berasal dari "khalaqa" atau "khalqun" artinya kejadian serta erat hubungannya dengan "Khaliq", artinya menciptakan, tindakan atau perbuatan, sebagaimana terdapat kata" al-khaliq" artinya pencipta dan "makhluq" artinya yang diciptakan.

Akhlak ibarat keadaan jiwa yang kokoh, timbul berbagai perbuatan dengan mudah tanpa menggunakan fikiran dan perencanaan. Bilamana perbuatan-perbuatan yang timbul dari jiwa itu baik, maka keadaannya disebut "akhlak yang baik". Namun jika yang ditimbulkan lebih dari itu, maka keadaannya disebut "akhlak yang buruk". Akhlak didalamnya meliputi karakter, sifat, sikap, tabi'at dan perilaku yang melekat pada diri setiap muslim. Sehingga baik dan buruknya akhlak sangat menentukan derajat muslim itu sendiri. Bahkan Rasulullah SAW menjadikan baik buruk akhlak seseorang sebagai kualitas imannya. Rasulullah SAW bersabda yang artinya: "Orang mukmin yang sempurna imannya adalah yang paling baik akhlaknya." (HR.Tirmidzi)

Namun kenyataan seakan berbicara, bahwa dizaman yang semakin dewasa ini, dimana teknologi berkembang sangat cepat dan informasi menjangkau lebih luas, sangat mudah kita dapati akhlak para generasi muda khususnya pemuda-pemudi Islam yang sangat jauh melenceng dari ajaran dan tuntunan Islam yang seharusnya mereka terima. Mulai dari gaya berbusana, cara berbicara, perilaku dan lain sebagainya. Hal ini tidak lain karena saat ini terlalu kuatnya arus informasi tentang budaya hidup dan perilaku dari berbagai sudut dunia. Kebanyakan pemuda saat ini dengan sengaja ikut terseret demi sebuah alasan trend. Saat ini sangat lumrah kita temukan pemuda yang meng“enteng"kan shalat berjama'ah di masjid. Sangat mudah kita dapati remaja putri rela digandeng teman laki-lakinya meski menyadari dirinya berhijab. Anak-anak muda yang lebih bangga menenteng smartphone jutaan rupiah dibandingkan dengan mushaf untuk sekedar dibaca. Belum lagi siswa Sekolah 
Menengah Atas hingga Mahasiswa perguruan tinggi yang terlibat adu bentrok demi kepentingan golongan semata.

Ironinya di era modern ini, tantangan mayoritas lahir bukan dari luar Islam, melainkan lahir dari kalangan Islam itu sendiri. Mereka mengklaim bahwa merekalah yang paling benar di antara sesamanya, memisahkan diri dari saudara-saudaranya yang lain, lalu membentuk golongan dan kelompok tersendiri untuk mereka dan menganggap yang di luar kelompoknya adalah sesat. Sehingga muncullah problematika baru, adanya saling menyesatkan antara satu kelompok terhadap kelompok yang lain, yang mana sumber utama dari permasalahan itu semua adalah dikarenakan hilangnya akhlak seorang muslim secara individu. Ini menjadi tugas kita semua, tugas para santri dan para ulama yang notabenenya adalah pewaris para nabi untuk menyebarkan Islam sejati yang dibangun atas fondasi akhlak mulia.

Yang demikian hanyalah sekian contoh dari beberapa kasus, merosotnya kadar Akhlaqul Karimah di kalangan muslim. Yang paling membuat miris adalah dari kalangan merekalah yang kerap terlihat "anti" dengan tuntunan agama sendiri. Mereka adalah hasil didikan zaman globalisasi yang mengikuti budaya Barat dan dijadikan sebagai kiblat perilaku serta mengabaikan nasihat agama dan orang tua.

Berdasarkan uraian tersebut, maka dipandang perlu untuk diadakan gerakan pembinaan akhlak dikalangan muslim. Pembinaan akhlak ini diharapkan akan menciptakan pola pikir kreatif dan kritis dalam menghadapi arus globalisasi serta dapat tetap mempertahankan kemuliaan Islam ditengah maraknya degradasi akhlak muslim. Tulisan ini menawarkan sebuah konsep gerakan pembinaan akhlak dengan menggunakan metode IDT (Ikhtiar, Doa, Takwa).

Pembinaan akhlak peserta didik menjadi sesuatu yang didambakan oleh setiap orang dalam proses pendidikan, sebab akhlak memiliki fungsi menjadikan perilaku manusia menjadi lebih beradab serta mampu mengidentifikasi berbagai persoalan kehidupan, baik atau buruk menurut norma yang berlaku. Oleh karena itu, perhatian terhadap akhlak menjadi salah satu fokus utama diselenggarakannya pendidikan di Indonesia.

Melalui pendidikan akhlak, seseorang akan dapat mengetahui mana yang benar dan mana yang buruk. Oleh karena itu, seiring berkembangnya zaman dan teknologi, pendidikan akhlak memiliki posisi yang strategis dalam pengendalian perilaku manusia. Dalam perjalanan pendidikan nasional, ada satu sisi yang menjadi bagian terpenting dalam usaha pembangunan moral bangsa, yakni pendidikan agama. Dalam UU No 20 Tahun 2003 tentang Sistem Pendidikan Nasional, pendidikan agama menjadi mata pelajaran wajib diseluruh jenjang pendidikan, mulai pendidikan dasar hingga pendidikan tinggi. Dengan pendidikan agama, diharapakan seorang individu dapat menjalani kehidupan sesuai dengan tuntunan dan ajaran agamanya, karena dalam agama semua aspek kehidupan diatur didalamnya. M.Arifin dalam bukunya menyebutkan bahwa pendidikan Islam merupakan sebuah proses yang mengarahkan manusia kepada kehidupan yang lebih baik dan mengangkat derajat kemanusiaannya, 
sesuai dengan kemampuan dasar (fitrah) dan kemampuan ajarannya (pengaruh dari luar).

Pembinaan akhlak dengan metode IDT (Ikhtiar, Doa, Takwa) ini diterapkan di SMP IT Al-Wasi Desa Neglasari, Kecamatan Cisompet, Kabupaten Garut yang menjadi salah satu sarana pendidikan agama bagi masyarakat sebagai solusi pengimplementasian tujuan pendidikan nasional dalam mendidik moral bangsa yang sampai saat ini masih terbilang belum maksimal. Ikhtiar sebagai langkah awal dalam menata akhlak, mulai dari akhlak terhadap manusia sampai kepada akhlak terhadap Allah SWT. Firman Allah SWT di dalam surat Ar-Ra'd ayat 11 sebagai berikut:

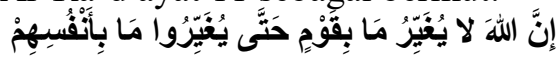

Artinya: "Sesungguhnya Allah tidak akan mengubah keadaan suatu kaum sehingga mereka mengubah keadaan yang ada pada diri mereka sendiri." (Q.S. Ar-Ra'd: 11)

Kemudian setelah usaha dilakukan, langkah selanjutnya adalah berdoa atas apa yang diikhtiarkan. Allah SWT berfirman dalam surat Al Mu'min ayat 60 sebagai berikut:

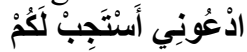

Artinya: “Berdoalah kepada-Ku, Aku akan mengabulkannnya.” (Q.S. Al Mu'min: 60)

Doa adalah penguat dan pendekat hati seorang hamba kepada-Nya dan akan memperlancar tercapainya apa yang diikhtiarkan dan dimohonkan sehingga nantinya sampai pada tahap yang ketiga yaitu takwa kepada Allah SWT dan merupakan tahap paling tinggi dalam proses pembinaan akhlak.

\section{Metode Penelitian}

Penelitian ini merupakan penelitian yang menggunakan jenis kualitatif yaitu penelitian yang sistematis digunakan mengkaji atau menteliti suatu objek pada latar alamiah tanpa ada manipulasi di dalamnya dan tanpa pengujian hipotesis, dengan metode-metode yang alamiah ketika hasil penelitian diharapkan bukanlah generalisasi berdasarkan ukuran-ukuran kuantitas, namun makna (segi kualitas) dari fenomena yang diamati. Penelitian ini menggunakan kata-kata dan rangkaian kalimat, bukan merupakan deretan angka atau statistik. Penelitian ini berusaha mendeskripsikan Pembinaan Akhlak dengan Metode IDT (Ikhtiar, Doa, Takwa).

Dalam penelian kualitatif sangat erat kaitannya dengan faktor kontekstual. Untuk mendapat informasi dan sumber data, dilakukan dengan wawancara atau pengamatan yang merupakan hasil usaha gabungan dari kegiatan melihat, mendengar, dan bertanya. Kegiatan ini akan bervariasi dari situasi satu dengan situasi yang lain. Berdasarkan uraian tersebut, peneliti dapat menetapkan sumber data untuk 
mendapatkan informasi tentang objek yang diteliti, adapun sumber data primer dari penelitian ini adalah data yang dikumpulkan peneliti dari sumber utamanya, diantaranya: 1) Kepala sekolah, sebagai informa untuk mengetahui perjalanan SMP IT Al-Wasi dari masa ke masa dan memiliki wewenang serta kebijakan adanya pendidikan akhlak mulia di SMP IT Al-Wasi, 2) Wakasek kurikulum, sebagai responden dalam penelitian ini untuk mengetahui dan menggali informasi yang berkaitan dengan proses pendidikan akhlak mulia dan usaha pihak sekolah dalam Pembinaan Akhlak dengan Sistem IDT (Ikhtiar, Doa, Takwa), 3) Tenaga Pendidik/Guru Pembina, yaitu guru pendidikan Akidah Akhlak sebagai responden untuk mengetahui jalannya proses pembinaan akhlak dengan metode IDT (Ikhtiar, Doa, Takwa) mulai dari perencanaan, pelaksanaan hingga evaluasi, 4) Peserta didik SMP IT Al-Wasi dan orang tua. Peserta didik bertindak sebagai subjek atau pelaku dalam pelaksanaan pembinaan akhlak ini. Hal ini untuk mendapatkan informasi mengenai pengetahuan dan respon peserta didik serta orang tua dalam pembinaan akhlak, serta upaya apa saja yang dilakukan oleh pihak sekolah maupun guru dalam pembinaan akhlak di SMP IT Al-Wasi. Sedangkan sumber data sekunder adalah sumber yang diperoleh peneliti tidak secara langsung dari subjek ataupun objek. Yakni dengan data dan dokumen-dokumen yang ada disekolah.

Metode pengumpulan data dalam penelitian ini dilakukan dengan: 1) Wawancara (Interview). Wawancara adalah percakapan dengan maksud tertentu. Wawancara dapat dilakukan secara terstruktur maupun tidak terstruktur, dan dapat dilakukan secara tatap muka (face to face) maupun menggunakan telepon. Peneliti menggunakan interview tidak terstruktur agar memberikan kebebasan kepada orang yang terinterview untuk memberikan tanggapan atau jawaban sendiri. Peneliti menggunakan cara ini agar mendapatkan data yang relevan dan tidak menginginkan kekakuan antara peneliti dengan yang terinterveiw. Dalam pelaksanaan peneliti akan mewawancarai Kepala Sekolah, Wakasek, dan guru Akidah Akhlak SMP IT Al-Wasi untuk mendapatkan data mengenai pembinaan akhlak dengan metode IDT (Ikhtiar, Doa, Takwa). 2) Observasi. Observasi adalah teknik pengumpulan data dengan suatu pengamatan, dengan disertai pencatatan-pencatatan terhadap keadaan atau prilaku atau objek sasaran. Motode observasi ini merupakan metode pendukung dalam penelitian ini, karena dengan metode observasi penulis dapat informasi secara langsung dan memperoleh data lebih rinci dan jelas. Observasi yang digunakan dalam penelitian adalah observasi nonpartisipan, yaitu bentuk observasi atau pengamatan, dimana peneliti tidak terlibat langsung atau tidak berperan secara langsung kedalam kegiatan yang diteliti. Metode ini penulis menggunakan untuk melihat pola pembinaan akhlak di SMP IT Al-Wasi. Dalam observasi penulis khususnya mengamati dalam hal pembinaan akhlak. 3) Dokumentasi. Dokumentasi adalah mencari data mengenai hal-hal atau variabel yang berupa catatan, rapat, buku, notulen dan sebagainya. Metode dokumentasi ini sebagai metode pendukung dari data yang telah diperoleh. Adapun dokumen yang digunakan adalah data yang tertulis tentang pembinaan akhlak di SMP IT Al-Wasi. 
Data dianalisis dengan kualitatif melalui teknik analisis reduksi data (data reduction), penyajian data (data display) dan penarikan kesimpulan (verifikasi) yaitu menyusun sistematis data yang diperoleh hasil wawancara, catatan lapangan dan hasil dokumentasi dengan cara mengorganisasikan data kedalam kategori, menjabarkan keunit-unit, melakukan sintesa, menyusun kedalam pola, memilih mana yang penting dan akan dipelajari, dan membuat kesimpulan sehingga dapat dipahami oleh diri sendiri maupun orang lain. 1) Data Reduction (Reduksi data). Mereduksi data berarti menerangkan, memilih hal-hal pokok, memfokuskan kedalam hal-hal yang penting, dicari tema dan membuang yang tidak perlu. Dengan demikan dapat dipahami dalam penyajian data ini akan dianalisis data yang bersifat deskriptif kualitatif yaitu dengan menguraikan seluruh konsep yang ada hubungannya dengan pembahasan penelitian. Oleh karena itu semua data-data dilapangan yang berupa dokumen hasil wawancara, hasil observasi dan lain sebagainya, akan dianalisis sehingga dapat memunculkan deskripsi tentang pembinaan akhlak dengan sistem IDT (Ikhtiar, Doa, Takwa). Pada tahap reduksi data, data yang dikumpulkan observasi mengenai tentang pembinaan akhlak dengan sistem IDT (Ikhtiar, Doa, Takwa) di SMP IT Al-Wasi serta interview mengenai pembinaan akhlak. 2) Data Display (Penyajian data). Proses ini dilakukan untuk mempermudah peneliti dalam mengkontruksi data kedalam sebuah gambaran sosial yang utuh, selain itu untuk memeriksa sejauh mana kelenkapan data yang tersedia. 3) Verifikasi (Penarikan kesimpulan). Kesimpulan awal yang dikemukakan masih bersifat sementara dan akan berubah apabila ditemukan bukti-bukti yang kuat yang mendukung pada tahap pengumpulan data berikutnya.

Dalam menganalisis data hasil penelitian ini, penulis menggunakan cara analisis deskriptif kualitatif. Setelah data terkumpul dengan lengkap dari lapangan, perlu mengadakan penelitian sedemikian rupa untuk mendapatkan suatu kesimpulan yang berguna menjawab persoalan-persoalan yang diajukan dalam penelitian. Setelah data diperoleh, baik hasil penelitian kepustakaan maupun hasil penelitian lapangan, maka data itu diolah kemudian dianalisis, sehingga mendapatkan kesimpulan akhir. Data yang diolah adalah hal-hal yang tercantum dan terekam dalam catatan lapangan hasil wawancara atau pengamatan.

Dalam penelitian ini peneliti melakukan penelitian di Sekolah Menengah Pertama Islam Terpadu Al-Wasi yang beralamat di jalan Sindangpalay, Kampung Padarame, Desa Neglasari, Kecamatan Cisompet, Kabupaten Garut, Provinsi Jawa Barat.

Tanggal $\quad: 1$ Februari 2021

Waktu : $08.00-10.00 \mathrm{WIB}$

Subjek pada penelitian ini adalah peserta didik di SMP IT Al-Wasi Cisompet.

\section{Hasil Wawancara \\ Identitas Narasumber}

Nama : Sobar Sopandi, S.H.I. 
Jabatan : Kepala Sekolah SMP IT Al-Wasi Cisompet

\section{Catatan isi pembicaraan:}

1. Bagaimana teknik pelaksanaan pembinaan akhlak peserta didik di SMP IT AlWasi?

Narasumber : Teknik yang digunakan berupa pembiasaan serta peneladanan dari pihak sekolah kepada peserta didik.

2. Untuk materi Akhlak sendiri, model pembelajaran dan metode apa digunakan guru dalam proses pembelajaran?

Narasumber : Untuk metode pembelajaran, biasanya menggunakan metode ceramah terlebih dahulu kemudian diumpamakan kedalam kehidupan seharihari. Nah, agar anak-anak lebih memahami pembelajaran, biasanya digunakan metode mencontohkan langsung dengan melibatkan siswa.

3. Adakah media atau alat yang digunakan untuk mendukung proses pembelajaran? Narasumber : Untuk media/alat digunakan alat seadanya, misalnya berupa makanan atau alat tulis agar mereka tahu manfaat akhlak dalam penerapan dengan kehidupannya.

4. Bagaimana sikap peserta didik ketika pembelajaran sedang berlangsung?

Narasumber : Tidak menentu, kadang mereka fokus terhadap pembelajaran namun ada juga yang sering mengantuk dan tidak memperhatikan.

5. Terakhir, bagaimana cara Bapak melakukan penilaian atau evaluasi sebagai upaya pembinaan akhlak peserta didik?

Narasumber : Untuk evaluasi digunakan sistem tes dan non tes. Tes diberikan ketika ulangan harian, UTS ataupun UAS. Untuk non tes, maka guru mata pelajaran menilai secara langsung dengan pengawasan kepada anak apakah terdapat perubahan terhadap akhlak peserta didik atau tidak. Penilaian juga tidak hanya berorientasi ketika pembelajaran berlangsung namun selama peserta didik menjadi siswa disini.

\section{Pelaksanaan Pembinaan Akhlak dengan Metode IDT (Ikhtiar, Doa, Takwa) di SMP IT Al-Wasi Cisompet}

Pembinaan akhlak yang dilaksanakan di SMP IT Al-Wasi menggunakan metode IDT (Ikhtiar, Doa, Takwa) yang dilakukan secara menyeluruh dari awal peserta didik datang ke sekolah sampai kembali kerumah masing-masing.

1. Menanamkan nilai-nilai Agama

Berdasarkan hasil interview terhadap guru Akidah Akhlak, beliau mengatakan bahwa dalam pembinaan Akhlak di SMP IT Al-Wasi Cisompet dilakukan dengan menanamkan nilai-nilai agama Islam kepada peserta didik pada saat proses belajar mengajar sesuai dengan materi yang disampaikan.

Dalam proses pembelajaran pendidik harus memiliki totalitas dalam menjalankan tugasnya sebab yang memegang kendali dalam menghasilkan output yang handal adalah guru. Melalui perannya sebagai demonstrator, pengolaan kelas, mediator, fasilitator, pengajar dan evaluator, selain itu guru yang disebut ustadz, muallim, www.journal.uniga.ac.id 
murobby, mudarris, muaddih, maka guru hendak senantiasa menguasai bahan atau materi pelajaran yang akan diberikan kepada peserta didik.

Dengan demikian guru akan mudah menyajikan berbagai teori yang berkaitan dengan shalat dan mampu menginternilisasi niali-nilai ajaran Islam dalam kehidupan seharihari. Pemberian teori tentang nilai-nilai ajarana agama Islam kepada peserta didik terarah dan mempunyai dasar dalam dalam segala hal khususnya dalam pembahasan yang disampaikan.

Dalam proses belajar mengajar, guru Akidah Akhlak di SMP IT Al-Wasi Cisompet memberikan segala materi yang berkaitan dengan hal-hal ajaran Islam sesuai dengan Kurikulum yang ada seperti misalnya dalam keimanan kepada Allah SWT, keimanan kepada Malaikat-malaikat-Nya, keimanan kepada kitab-kitab yang diturunkan-Nya, keimanan kepada Rasul-rasul-Nya, keimana kepada Hari akhir dan beriman kepada Qadha dan Qodar. Selain itu diberikan tata cara berakhlak kepada Allah SWT, tata cara berakhlak kepada Rasulullah SAW, tata cara berakhlak kepada orang tua, tata cara berakhlak kepada guru, hingga kepada alam dan sekitarnya.

2. Memberikan contoh perbuatan yang baik

Berdasarkan hasil observasi dapat disimpulkan bawha pembinaan akhlak di SMP IT Al-Wasi Cisompet dengan melihat guru Akidah Akhlak yang sangat sopan, bertutur kata dengan baik atau lemah lembut serta ramah terhadap sesama. Hal ini dimaksudkan agar peserta didik dapat meniru terhadap perbuatan seorang pendidik dengan menerapkan kebiasaan tersebut dalam kehidupan sehari-hari.

Selain itu juga guru Akidah Akhlak juga membiasakan bila bersama terhadap orang laian semisal dengan guru lain, orang tua, maupun terhadap peserta didik selalu mengucapakan salam dengan bertujuan agar tahu betapa pentingnya mengucapakan salam dan menjawabnya sehingga dapat menerapakan dengan membiasakan dari kecil hingga dewasa tak akan pernah hilang ataupun lupa.

3. Mengadakan kegiatan keagamaan

Dalam mengadakan kegiatan keagamaan di SMP IT Al-Wasi Cisompet dapat dicontohkan misalnya memperingati hari besar Islam, Maulid Nabi Muhammad SAW, tahun baru Islam, Isra' Mi'raj dan lainnya. Dilakukan kegiatan ini agar peserta didik selalu mengingat dan meneladani sunnah-sunnah Rasulullah dalam kehidupan sehari-hari sebagai realisasi pembinaan akhlak dengan metode IDT (Ikhtiar, Do'a, Takwa).

4. Materi Pembinaan Akhlak di SMP IT Al-Wasi Cisompet

Pembinaan akhlak dengan metode IDT (Ikhtiar, Doa, Takwa) yang diterapkan di SMP IT Al-Wasi Desa Neglasari, Kecamatan Cisompet, Kabupaten Garut yang menjadi salah satu sarana pendidikan agama bagi peserta didik sebagai solusi pengimplementasian tujuan pendidikan nasional dalam mendidik moral bangsa yang 
sampai saat ini masih terbilang belum maksimal. Ikhtiar sebagai langkah awal dalam menata akhlak, mulai dari akhlak terhadap manusia sampai kepada akhlak terhadap Allah SWT. Firman Allah SWT di dalam surat Ar-Ra'd ayat 11 sebagai berikut:

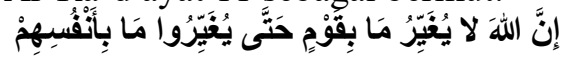

Artinya: "Sesungguhnya Allah tidak akan mengubah keadaan suatu kaum sehingga mereka mengubah keadaan yang ada pada diri mereka sendiri." (Q.S. Ar-Ra'd: 11)

Kemudian setelah usaha dilakukan, langkah selanjutnya adalah berdoa atas apa yang diikhtiarkan. Allah SWT berfirman dalam surat Al Mu'min ayat 60 sebagai berikut:

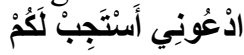

Artinya: "Berdoalah kepada-Ku, Aku akan mengabulkannnya.” (Q.S. Al Mu'min: 60)

Doa adalah penguat dan pendekat hati seorang hamba kepada-Nya dan akan memperlancar tercapainya apa yang diikhtiarkan dan dimohonkan sehingga nantinya sampai pada tahap yang ketiga yaitu takwa kepada Allah SWT dan merupakan tahap paling tinggi dalam proses pembinaan akhlak.

\section{Evaluasi Pembinaan Akhlak dengan Metode IDT (Ikhtiar, Doa, Takwa) di SMP IT Al-Wasi Cisompet}

Menurut Zainul dan Nasution (2001), evaluasi merupakan suatu proses pengambilan keputusan dengan menggunakan informasi yang di peroleh melalui pengukuran suatu hasil belajar, baik yang menggunakan instumen tes maupun non tes.

Pengertian evaluasi dibagi menjadi tiga istilah yaitu "evaluasi" (evaluation), "pengukuran" (measurement), dan "penilaian" (assessment). Evaluasi berasal dari kata evaluation (bahasa Inggris). Istilah "penilaian" merupakan kata benda dari "nilai". Pengertian "pengukuran" mengacu pada kegiatan membandingkan sesuatu hal dengan satuan ukuran tertentu, sehingga sifatnya menjadi kuantitatif. Evaluasi merupakan suatu proses atau kegiatan pemilihan, pengumpulan, analisis dan penyajian informasi yang dapat digunakan sebagai dasar pengambilan keputusan serta penyusunan program selanjutnya. Evaluasi juga berarti proses mengumpulkan data dasar dan menelaah misalnya tentang efektifitas program belajar dan pembelajaran, seperti dalam kegiatan pembelajaran, kebijakan dan prosedur pelaksanaan program pembentukan perilaku, atau pengembangan kemampuan dasar.

Agar tujuan evaluasi dapat terwujud sesuai dengan prinsip-prinsip yang mendasari syarat-syarat yang diperlukan, pelaksanaannya menyesuaikan langkah atau prosedur evaluasi yang benar. Dalam hal ini harus mempunyai perencanaan dan teknik dalam pelaksanaan evaluasi secara tepat dan benar agar hasil dari evaluasi benar-benar menggambarkan kemampuan siswa sebenarnya. 
Dalam pelaksanaan evaluasi pembinaan akhlak memerlukan beberapa aspek yaitu: perencanaan, pelaksanaan, dan pengolahan hasil evaluasi dan dari aspek tersebut dapat dilaksanakan evaluasi yang terencana dengan baik. Melalui proses penelitian, peneliti memperoleh informasi bahwa pelaksanaan evaluasi pembinaan akhlak di SMP IT Al-Wasi tidak hanya menekankan pada prosedur evaluasinya saja, tetapi juga menekankan pada prinsip dan tujuan evaluasi. Dalam pelaksanaan evaluasi pembinaan akhlak mereka melakukan 3 tahapan yaitu tahap perencanaan, pelaksanaan dan pengolahan.

Dalam pelaksanaan evaluasi, mereka terkadang melakukan evaluasi di awal (pretest), di tengah, dan di akhir pembelajaran (postest). Evaluasi pembelajaran pada pembinaan akhlak di SMP IT Al-Wasi dapat dinilai berjalan dengan baik dan berhasil. Kriteria baik dan berhasil tersebut ditandai dengan beberapa indikator yaitu perubahan dalam aspek akhlak peserta didik.

\section{Faktor Pendukung dan Penghambat Pembinaan Akhlak dengan Metode IDT (Ikhtiar, Doa, Takwa) di SMP IT Al-Wasi Cisompet}

Dapat kita ketahui dalam setiap program pasti ada faktor yang menghambat sehinga dapat dikatakan berhasil apabila menyelesaikan permasalahan tersebut. Berdasarkan dari data yang peneliti ambil dari hasil wawancara dan pengamatan yang dapat diidentifikasikan faktor pendukung dan penghambat terhadap pembinaan akhlak dengan metode IDT (Ikhtiar, Doa, Takwa) di SMP IT Al-Wasi Cisompet, diantaranya:

\section{a. Faktor pendukung}

1. Komitmen Kepala Sekolah, Guru dan Orang tua

Berdasarkan hasil observasi dari SMP IT Al-Wasi Cisompet mendapatkan keterangan bahwa faktor pendukung untuk pembinaan akhlak adalah adanya komitmen dari Kepala Sekolah untuk memajukan sekolah, meningkatkan kedisiplinan dan akhlak guru beserta peserta didik.

Hal ini tergambar bahwa Kepala Sekolah memang berkewajiban atau keharusan dalam kepemimpinannya untuk memajukan sekolah, dengan melakukan berbagai hal yang bermanfaat bagi semua orang baik untuk guru, staf, peserta didik dan umumnya bagi masyarakat sekitar. Oleh karena itu Kepala Sekolah akan tetap berkomitmen dalam melaksanakan kebijakan dan peraturan yang telah dibuat dan bilamana adanya ketidakberhasilan maka akan melakukan evaluasi untuk memperbaiki dengan bertujuan memajukan sekolah.

Kemudian, guru juga berperan sebagai salah satu faktor pendukung karena gurulah yang menguasai kendali dengan penuh terhadap akhlak peserta didik. Jika ada seorang guru yang meliki sikap acuh tak acuh terhadap akhlak peserta didik dapat disimpulkan bahwa peserta didik akan memiliki akhlak yang buruk. Oleh karena itu, konsisten 
seorang guru sangat diperlukan untuk pembinaan akhlak peserta didik menjadi lebih baik lagi.

Selain Kepala Sekolah dan guru, perannya orang tua terhadap anak sangatlah penting dalam pembinaan akhlak setelah peserta didik pulang dan sampai dirumah, orang tua diharapkan melakukan penanaman agama Islam dalam kehidupan sehari-hari dapat dilakukan dengan anjuran atau perintah agar anak-anak mereka mengikuti sekolah agama dan melaksanakan kewajibannya yaitu shalat lima waktu pada waktunya.

\section{Sarana dan Prasarana}

Berdasarkan hasil dokumentasi, SMP IT Al-Wasi Cisompet memiliki sarana gedung yang memadai, sehingga dapat mendukung dalam pembinaan akhlak peserta didik

\section{Peran Serta Orang Tua}

Partisipasi aktif dan kesadaran orang tua dalam mendukung setiap program pembinaan akhlak siswa di SMP IT Al-Wasi Cisompet menjadikan motivasi terhadap anaknya.

\section{b. Faktor Penghambat}

Selain faktor pendukung ada juga faktor penghambat dalam pembinaan akhlak di SMP IT Al-Wasi Cisompet yang teridentifikasi sebagai berikut:

1. Perkembangan Ilmu Pengetahuan dan Teknologi Modern

Perkembangan ilmu pengetahuan dan teknologi modern seperti adanya televisi, handphone, komputer dan sebagainya. Selain membawa manfaat bagi manusia di seluruh dunia seperti dapatnya berkomunikasi jauh, berjual beli online, dan mendapatkan informasi baik nasional dan internasional. Namun disisi lain dapat mendatangkan suatu kemadharatan (bahaya) bagi pengguna teknologi yang canggih dengan salah, kondisi ini juga terjadi pada anak-anak SMP IT Al-Wasi Cisompet, dimana perkembangan teknologi khususnya HP dan komputer selain menjadikan alat yang bermanfaat dalam menjalin silaturahmi dan keperluan belajar, ternyata juga banyak dimanfaatkan untuk hal-hal yang negatif seperti mengakses gambar atau video yang sangat tidak mendidik dan bertentangan dengan ajaran Agama Islam.

Kondisi tersebut dapat berdampak pada pembinaan akhlak siswa di SMP IT Al-Wasi Cisompet, dimana situs yang berbau fornografi dan fornoaksi dapat dengan mudah diakses sehingga menimbulkan berbagai macam melanggar kesusilaan dan situs yang mengajarkan kekerasan juga akan bedampak terhadap mentalitas anak-anak.

\section{Lingkungan Pergaulan Peserta Didik yang Kurang Baik}

Kendala lain yang diharapi Guru Akidah Akhlak di SMP IT Al-Wasi Cisompet dalam melakukan pembinaan akhlak peserta didik adalah lingkungan pergaulan peserta didik yang kurang baik. Dalam pelaksanaan pembinaan akhlak peserta didik telah di 
perintah agar menjauhi akan tetapi teman pergaulannya sangatlah kuat pengaruhnya, terkadang upaya yang dilakukan guru dengan berkonsultasi kepada Kepala Sekolah dan guru lainnya untuk mencari solusi akibat pergaulan yang kurang baik akhlaknya. Biasanya dilakukan dengan pemisahan kelas akan tetapi solusi tersebut sangat minim terhadap hasilnya karena selepas sekolah anak dapat berteman seperti biasanya.

\section{Kurangnya Perhatian Orang Tua terhadap Peserta Didik}

Menurut Guru Akidah Akhlak di SMP IT Al-Wasi Cisompet faktor lain yang menjadi penghambat dalam pembinaan akhlak yaitu kurangnya perhatian orang tua terhadap anaknya dalam perkembangan dan pertumbuhannya. Sehingga anak-anak dibebaskan untuk bergaul dengan anak-anak yang kurang baik dalam akhlaknya dikarenakan kesibukan orang tua mencari nafkah dan bisa terjadi karena kemiskinan.

Hal ini dipertegas oleh guru pembinaan akhlak karena adanya anak yang selalu melakukan pelanggaran sekolah adalah siswa yang dari keluarganya kurang harmonis, saling sibuk mencari nafkah dan faktor paling rendah dalam kondisi ekonomi yang kurang.

\section{Kurangnya Kemauan Peserta Didik untuk Mengubah Akhlaknya}

Peran guru dalam pembianan akhlak peserta didik merupakan faktor diluar peserta didik. Artinya guru Akidah Akhlak hanya bisa memberikan arahan serta bimbingan. Akan tetapi dalam pelaksanaan pembinaan akhlak akan kembali lagi terhadap peserta didik untuk merubah akhlaknya yang kurang baik menjadi baik berada ditangan peserta didik tersebut. Apabila peserta didik yang kurang kemauan untuk mengubah akalanya menjadi baik sangatlah berpengaruh terhadap keberhasilan pembinaan akhlak peserta didik.

Dari berbagai cara dalam pelaksanaan pembinaan akhlak bila peserta didik banyak yang bertekad untuk memperbaiki akhlaknya akan kemungkinan besar keberhasilan guru dalam pelaksanaannya akan tetapi bila peserta didik tersebut memiliki sikap acuh tak acuh semakin minim keberhasilan dalam pembinaannya sehingga dapat disimpulkan bahwa faktor penghambat salah satunya kurang kemauan dari peserta didik untuk merubah akhlaknya sendiri.

\section{Kesimpulan}

Berdasarkan penelitian yang telah dilakukan oleh peneliti maka dapat disimpulkan bahwa penerapan model IDT (Ikhtiar, Doa, Takwa) pada proses pembinaan akhlak peserta didik di SMP IT Al-Wasi dilaksanakan dengan baik dan sesuai dengan langkah-langkah model IDT (Ikhtiar, Doa, Takwa) dalam pembinaan akhlak peserta didik. Hasil penelitian menunjukkan bahwa terdapat peningkatan akhlakul karimah dalam diri peserta didik mulai dari gaya berbusana, cara berbicara, perilaku, bahasa, cara berhadapan dengan orang lain serta dalam pemilihan dan pemilahan lingkungan pergaulan peserta didik. 


\section{Daftar Pustaka}

Al-Qur'anul Karim

Ahmad, Noor. 2019. Epistemologi Pendidikan Islam. Yogyakarta: Walisongo Expres.

Ahmad, Noor. 2019. Epistemologi Syara’. Yogyakarta: Walisongo Expres.

Anwar, Syahrul. 2010. Akhlak Islamiyah. Bogor: Ghalia Indonesia.

Anwar, Syahrul. 2010. Ilmu Pendidikan Islam. Bogor: Ghalia Indonesia.

Bungin, B. 2015. Metodologi Penelitian Kualitatif. Jakarta: Fajar Interpratama Grafika.

Khatibah, K. 2011. Penelitian Kepustakaan. Iqra': Jurnal Perpustakaan dan Informasi. Mubarok, Dr. Jaih. 2015. Hukum Islam. Bandung: Remaja Rosdakarya.

Nasrullah, R. 2015. Akhlak (Perspektif Komunikasi, Budaya, dan Sosioteknologi). Jakarta: Simbiosa Rekatama Media.

Qardhowi, Yusuf. 2014. Akhlak Islam. Jakarta: Gema Insani Press.

Silalahi, U. 2016. Penulisan Ilmiah. Bandung: Unpar Press.

Silalahi, U. 2016. Penulisan Ilmiah. Bandung: Unpar Press.

Sugiyono. 2018. Metode Penelitian Kuantitatif Kualitatif dan R\&D. Yogyakarta: Alfabeta.

Sukmadinata, N.S. 2016. Metode Penelitian Pendidikan. Bandung: Remaja Rosdakarya.

Sukmadinata, N.S. 2016. Metode Penelitian Pendidikan. Bandung: Remaja Rosdakarya.

Zed, M. 2008. Metode Penelitian Kepustakaan. Jakarta: Yayasan Obor.

Zhou, Coronavirus Prevention Handbook; Kemkes, "Tentang Novel Coronavirus (NCOV)";

World Health Organization, "Coronavirus." 